\title{
Effectiveness of Cimetidine as Adjuvant Therapy in the Treatment of Acute-Extrinsic Atopic Dermatitis: A Double-Blind Randomized Controlled Trial
}

\author{
Endi Novianto (D) - Tjut N. A. Jacoeb · Wresti Indriatmi • \\ Suhendro · Rianto Setiabudy · Rahajuningsih D. Setiabudy • \\ Murdani Abdullah · Iris Rengganis · Oki Suwarsa · Retno W. Soebaryo
}

Received: December 14, 2021 / Accepted: January 27, 2022 / Published online: February 17, 2022

(C) The Author(s) 2022

\section{ABSTRACT}

Introduction: Acute extrinsic atopic dermatitis (AD) requires long-term treatment. Cimetidine could be used as an adjuvant therapy for acuteextrinsic AD due to immunomodulatory effects. This study aims to assess the effectiveness of cimetidine as an adjuvant to standard treatment in acute extrinsic AD.

Methods: This is a double-blind randomized controlled trial involving $26 \mathrm{AD}$ patients aged

\footnotetext{
E. Novianto $(\varangle) \cdot$ T. N. A. Jacoeb · W. Indriatmi · R. W. Soebaryo

Department of Dermatology and Venereology, Faculty of Medicine Universitas Indonesia, Dr. Cipto Mangunkusumo National Central General Hospital, 6 Salemba Raya, Central Jakarta, Jakarta 10430, Indonesia

e-mail: drendinovianto@gmail.com
}

Suhendro $\cdot$ M. Abdullah $\cdot$ I. Rengganis Department of Internal Medicine, Faculty of Medicine Universitas Indonesia, Dr. Cipto Mangunkusumo National Central General Hospital, 6 Salemba Raya, Central Jakarta, Jakarta 10430, Indonesia

R. Setiabudy

Department of Pharmacology and Therapeutics,

Faculty of Medicine Universitas Indonesia, 6

Salemba Raya, Central Jakarta, Jakarta 10430, Indonesia
12-60 years from 2017 to 2020 . Effectiveness of cimetidine was assessed by comparing SCORing Atopic Dermatitis (SCORAD) and objective SCORAD changes in both groups at week 2, 4, 6, and 8. Serum levels of immunoglobulin E (IgE), interferon (IFN)- $\gamma$, interleukin (IL)-12, and IL-4 were also documented.

Results: Significant differences were observed in SCORAD changes at week $2,4,6$, and 8 $(p=0.004 ; p=0.001 ; p<0.001 ;$ and $p<0.001$ respectively), objective SCORAD changes at week $2,4,6$, and $8(p=0.004, p=0.001$,

\author{
R. D. Setiabudy \\ Department of Clinical Pathology, Faculty of \\ Medicine Universitas Indonesia, Dr. Cipto \\ Mangunkusumo National Central General Hospital, \\ 6 Salemba Raya, Central Jakarta, Jakarta 10430, \\ Indonesia \\ O. Suwarsa \\ Department of Dermatology and Venereology, \\ Faculty of Medicine Universitas Padjajaran, Hasan \\ Sadikin General Hospital, 38 Pasteur, Bandung \\ 40161, West Java, Indonesia
}


$p<0.001$, and $p<0.001$ respectively), and IgE level changes at week $8(p=0.002)$ between the two groups. However, there were no significant changes in IFN- $\gamma$, IL-12, and IL-4 levels between the two groups.

Conclusion: Cimetidine is a safe and effective adjuvant therapy for acute-extrinsic AD.

Trial Registration: NCT04018131.

Keywords: Atopic dermatitis; Cimetidine; Efficacy; IgE level; SCORAD

\section{Key Summary Points}

Atopic dermatitis (AD) is a chronic relapsing inflammatory skin disorder that causes burden worldwide

Acute extrinsic $\mathrm{AD}$ patients require longterm treatment to reduce the disease severity and prevent a recurrence

Cimetidine is a safe and effective adjuvant therapy for acute-extrinsic AD

The administration of cimetidine with dose $25-40 \mathrm{mg} / \mathrm{kg}$ along with standard treatment in acute extrinsic $\mathrm{AD}$ patients can reduce $\mathrm{AD}$ severity and serum IgE level as well as prevent progression into chronic AD

\section{INTRODUCTION}

Atopic dermatitis (AD) is a chronic relapsing inflammatory skin disorder that causes patient burden worldwide. The prevalence of $\mathrm{AD}$ is approximately $34 \%$ in children aged 12 years and $2-6 \%$ in adults $[1,2]$. AD is often associated with other atopic diseases, e.g., allergic rhinitis, bronchial asthma, and allergic conjunctivitis. The pathogenesis of AD is a complex combination of various interrelated factors, including genetics, environmental factors (humidity and irritants), immune system dysregulation, psychological factors, and infection [3, 4].
$\mathrm{AD}$ is classified into acute and chronic phases based on the disease course and morphology of skin abnormalities. Furthermore, based on serum immunoglobulin $\mathrm{E}$ (IgE) levels, $\mathrm{AD}$ is classified into extrinsic and intrinsic AD. Extrinsic AD is characterized by increased serum IgE levels with occurrence of $70-90 \%$ AD cases while intrinsic $\mathrm{AD}$ is characterized by normal serum IgE levels with occurrence of $10-30 \%$ of $\mathrm{AD}$ cases $[4,5]$. $\mathrm{AD}$ patients often require longterm treatment to reduce the disease severity and prevent recurrences. The economic and social burden experienced by AD patients leads to impaired quality of life [6]. To date, there is no effective and safe systemic drug to reduce $\mathrm{AD}$ severity and prolong remission. The available systemic drugs for $\mathrm{AD}$ are generally immunosuppressants with severe side effects [7].

Use of standard topical treatment including moisturizers and corticosteroids as well as systemic histamine-1 receptor antagonist (H1RA) has not been able to completely prevent the recurrence of $\mathrm{AD}[2,7]$. Cimetidine, a histamine-2 receptor antagonist (H2RA), has immunomodulatory properties that can potentially be used for acute-extrinsic $\mathrm{AD}$ treatment [8]. To date, there has been no evidence that cimetidine can improve the clinical severity or immunological parameters of acute extrinsic AD.

The study aims to assess the effectiveness and safety of cimetidine as an adjuvant to standard $\mathrm{AD}$ treatment in acute extrinsic $\mathrm{AD}$ patients in terms of decreasing SCOring Atopic Dermatitis (SCORAD), objective SCORAD, serum IgE and interleukin (IL)-4 levels, as well as increasing serum interferon (IFN)- $\gamma$ and IL-12 levels.

\section{METHODS}

\section{Study Design}

This is a double-blind randomized controlled trial conducted from October 2017 to July 2021 in the Department of Dermatology and Venereology, Dr. Cipto Mangunkusumo National Central General Hospital, and Medistra Hospital at Jakarta, Indonesia. The study was 
conducted in accordance with the Declaration of Helsinki, the International Conference on Harmonization Good Clinical Practice guideline, and applicable regulatory requirements. This study has been reviewed and approved by Health Research Ethics Committee of Faculty of Medicine Universitas Indonesia, approval number 1075/UN2.F1/ETIK/2017. All patients provided written informed consent before participating in the study.

\section{Participants and Sample Size}

Patients aged 12-60 years old who were diagnosed with AD based on Hanifin and Rajka criteria with acute clinical lesions (pruritus, erythematous papules, erosions, excoriations), serum IgE levels > $150 \mathrm{IU} / \mathrm{ml}$, and body weight of minimum $15 \mathrm{~kg}$ were recruited into the study. Exclusion criteria were use of systemic corticosteroids and immunosuppressants for the last 2 weeks, presence of chronic lesions (lichenification), use of drugs potentially interacted with cimetidine, suffering from diseases that can increase serum IgE level as well as abnormalities in routine blood count, liver function, and renal function test. The calculation of sample size resulted in a minimum of 13 samples in both arms to achieve power of $80 \%$.

\section{Randomization}

Permuted block randomization was conducted by the analyst with a computer. The allocation was written consecutively in numbered sealed envelopes. Both the main investigator and subjects did not know the allocation sequence. The subjects were given the envelopes consecutively according to the time of recruitment.

\section{Intervention}

History taking, physical examination, and measurement of SCORAD and objective SCORAD scores were performed. A total of $10 \mathrm{ml}$ vein blood was collected for assessment of serum IgE, IFN- $\gamma$, IL-12, and IL-4 levels. Prior to the data collection, cimetidine was prepared in the form of a 100-mg capsule, same as the preparation for placebo. The dose for each subject was $25-40 \mathrm{mg} / \mathrm{kg}$ daily with maximum dose of $1200 \mathrm{mg}$ daily. Subjects with body weight $15-24 \mathrm{~kg}$ received 2 capsules tid, subjects with body weight $24-36 \mathrm{~kg}$ received 3 capsules tid, and subjects with body weight $>36 \mathrm{~kg}$ received 4 capsules tid.

The subjects were randomized into treatment group and control group. All subjects received the intervention according to their allocation sequence. Aside from the intervention, all subjects were provided with information regarding the diseases, avoidance of precipitating factors, and skin care. Moisturized soap, ceramide lotion (moisturizers) bid, topical steroid agents (desonide $0.05 \%$ cream or clobetasol propionate $0.05 \%$ cream bid), and oral cetirizine $10 \mathrm{mg}$ qd were given to all subjects to be used daily. To ensure consistency of topical therapy, each subject was given a book to document the time of topical therapy's application. Subjects were followed up every 2 weeks for 8 weeks. SCORAD score, objective SCORAD score, and adverse events were documented at each follow-up visit. Laboratory examination was repeated at week 8 .

\section{Outcomes}

The primary outcome was effectiveness of cimetidine, which was assessed by improvement of SCORAD, SCORAD50, and objective SCORAD scores. Secondary outcomes were visual analog scale (VAS) for pruritus and sleep disorder, decrease of serum IgE and interleukin (IL)-4 levels, as well as increase of serum interferon (IFN)- $\gamma$ and IL-12 levels.

\section{Statistical Analysis}

Data analyses were performed with STATA $^{\circledR}$ version 16 (StataCorp LP, College Station, TX, USA). Continuous data were presented in the forms of mean (standard deviation) if the distribution was normal or median (interquartile range) if the distribution was not normal. Comparison of continuous data between both groups was analysed with independent $t$-test if the distribution was normal or Mann-Whitney 
test if the distribution was not normal. Comparison of categorical data between both groups was analysed with chi-squared test if the requirements are fulfilled or Fisher exact test if not. $p<0.05$ is considered significant.

\section{RESULTS}

\section{Baseline Characteristics}

A total of 26 subjects were recruited into the study who were randomized 1:1 to treatment group and control group. One subject in treatment group and one subject in control group dropped out from the study because of an adverse event (gastric discomfort) and difficult access to the hospital. Algorithm of the study enrolment is presented in Fig. 1. Overall, there were no significant differences in baseline characteristics of subjects between both groups. The baseline characteristics of the subjects are presented in Table 1.

\section{Changes on SCORAD Score}

The mean SCORAD scores at baseline were not significantly different between treatment group (43.90) and control group (35.23) $(p=0.170$; $95 \%$ confidence interval $[\mathrm{CI}]=-4.00$ to 21.34 ). The SCORAD scores improved significantly at week $2,4,6$, and $8(p<0.05)$. The changes in SCORAD score at week $2,4,6$, and 8 in both groups are presented in Table 2 . The evaluation of SCORAD50 showed a higher percentage in the intervention group from week 2 to week 8 consistently with a significant difference shown from week $4 \quad(p<0.05)$. Evaluation of SCORAD50 at each follow-up visit is presented in Fig. 2.

\section{Changes in Objective SCORAD Score}

The mean objective SCORAD scores at baseline were not significantly different between treatment group (36.98) and control group (28.90) $(p=0.096 ; 95 \%$ CI $1.54-17.71)$. The objective SCORAD scores also improved significantly at week $2,4,6$, and $8(p<0.05)$. The changes in objective SCORAD score at week 2, 4, 6, and 8 in both groups are presented in Table 3 .

\section{Subjective Symptoms}

Subjective symptoms are represented by VAS for pruritus and sleep. The initial VAS for pruritus was $4.08 \pm 3.29$ in the control group and $4.58 \pm 3.29$ in the intervention group $(p=0.713)$. The VAS for sleep was $1(0-8)$ in the control group and $2.17 \pm 2.12$ in the intervention group ( $p=0.832$ ). The changes in VAS for pruritus and sleep at week 2, 4, 6, and 8 in both groups are shown in Table 4. Significant changes in VAS for pruritus were demonstrated at week 6 and $8(p<0.05)$. Although not all comparisons demonstrate significant differences, the changes in VAS for pruritus and sleep were always higher in the intervention group.

\section{Changes in Serum IgE, IFN- $\gamma$, IL-4, and IL- 12 Levels}

The mean serum IgE, IFN- $\gamma$, IL-4, and IL-12 levels at baseline were not significantly different between the treatment group and control group $(p>0.05)$. After 8 weeks of treatment, the mean decrease of serum IgE levels in treatment group was superior compared to control group (102 vs -40 , respectively) $(p=0.002)$. At week 8 , the IgE levels were significantly lower in the treatment group than control group $(p=0.015)$. However, the improvement of serum IFN- $\gamma$, IL4 , and IL-12 levels at week 8 did not show significant differences between the treatment group and control group $(p>0.05)$. The comparison of serum IgE, IFN- $\gamma$, IL-4, and IL-12 levels before and after treatment was presented in Table 5.

\section{Adverse Events}

Gastric discomfort was reported by a subject in the treatment group at week 2 . The symptom improved after discontinuation of the treatment. However, the subject decided to drop out from the study. 


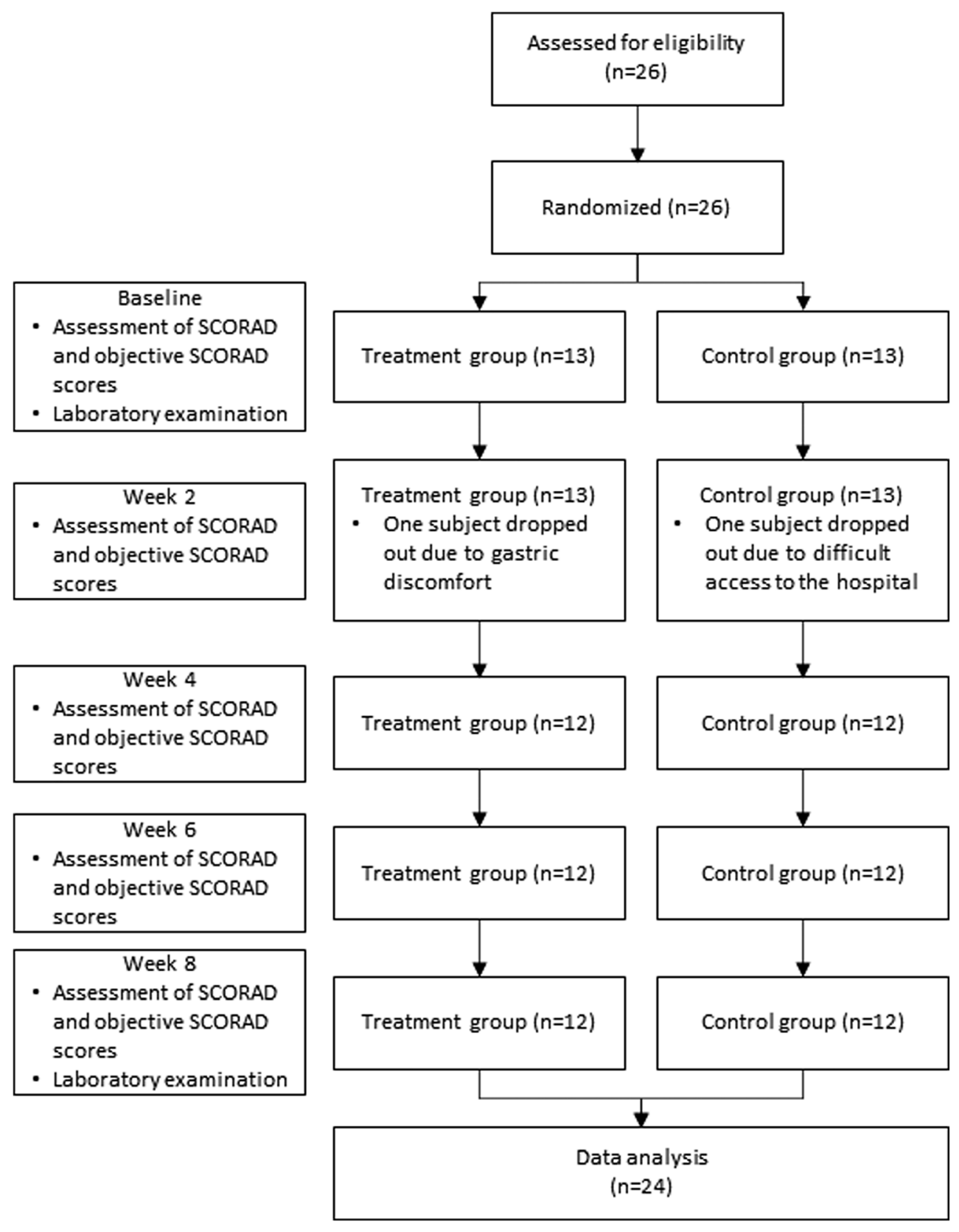

Fig. 1 Participant flow of the study

\section{DISCUSSION}

Cimetidine is a H2RA that was proven to exert immunomodulatory properties. At the dose of $25-40 \mathrm{mg} / \mathrm{kg}$ daily, cimetidine stimulates IL-12 production and decreases IL-10 production, leading to an increase in T-helper 1 (Th1) response and decrease in T-helper 2 (Th2) response. Cimetidine is also proven to increase IL-2 production, which will increase cellular immunity response and prevent the activation of T-cell suppressors. This process is expected to decrease IgE production and subsequently reduce AD severity [9].

The pleiotropic effects of histamine on immune system are mediated by four histamine 
Table 1 Baseline characteristics of the subjects

\begin{tabular}{|c|c|c|c|}
\hline Characteristics & Treatment group $(n=12)$ & Control group $(n=12)$ & $p$-value \\
\hline Age (years), mean $\pm S D$ & $29.58(11.57)$ & $30,91(6.73)$ & $0.733^{*}$ \\
\hline \multicolumn{4}{|l|}{ Gender } \\
\hline Male $(n)$ & 4 & 3 & \multirow[t]{2}{*}{$1000^{+}$} \\
\hline Female $(n)$ & 8 & 9 & \\
\hline \multicolumn{4}{|l|}{ Level of education } \\
\hline Secondary education & 3 & 4 & \multirow[t]{2}{*}{$1000^{+}$} \\
\hline Higher education & 9 & 8 & \\
\hline \multicolumn{4}{|l|}{ Marital status } \\
\hline Married & 7 & 7 & \multirow[t]{2}{*}{$1000^{+}$} \\
\hline Not married & 5 & 5 & \\
\hline \multicolumn{4}{|l|}{ Past treatment history } \\
\hline \multicolumn{4}{|l|}{ Topical agents } \\
\hline Yes & 10 & 8 & \multirow[t]{2}{*}{$0.640+$} \\
\hline No & 2 & 4 & \\
\hline \multicolumn{4}{|l|}{ Systemic agents } \\
\hline Yes & 10 & 11 & \multirow[t]{2}{*}{$1000^{+}$} \\
\hline No & 2 & 1 & \\
\hline
\end{tabular}

$n$ number of subjects, $S D$ standard deviation

Independent $t$-test

${ }^{+}$Fisher's exact test

Table 2 Changes in SCORAD score following intervention at week 2, 4, 6, and 8

\begin{tabular}{lllrl}
\hline Variables & $\begin{array}{l}\text { Treatment group } \\
(\boldsymbol{n}=\mathbf{1 2})\end{array}$ & $\begin{array}{l}\text { Control group } \\
(\boldsymbol{n}=\mathbf{1 2})\end{array}$ & $\boldsymbol{p}^{\text {-value }}{ }^{+}$ & CI 95\% \\
\hline$\Delta$ SCORAD score at week 2, mean (SD) & $14.52(6.83)$ & $6.31(6.88)$ & $0.004^{*}$ & $2.41-14.01$ \\
$\Delta$ SCORAD score at week 4, mean (SD) & $23.15(10.98)$ & $9.48(7.13)$ & $0.001^{*}$ & $5.83-21.51$ \\
$\Delta$ SCORAD score at week 6, mean (SD) & $32.13(12.11)$ & $11.28(6.09)$ & $<0.001^{*}$ & $12.73-28.97$ \\
$\Delta$ SCORAD score at week 8, mean (SD) & $36.53(12.80)$ & $10.90(6.18)$ & $<0.001^{*}$ & $17.12-34.15$ \\
\hline
\end{tabular}

CI confidence interval, $n$ number of subjects, SCORAD SCORing atopic dermatitis, SD standard deviation * Statistically significant

${ }^{+}$Independent $t$-test

receptors. The difference in the number of active and inactive receptors will determine the biological effects that occur. Activation of any types of histamine receptor can provide 


\section{SCORAD 50}

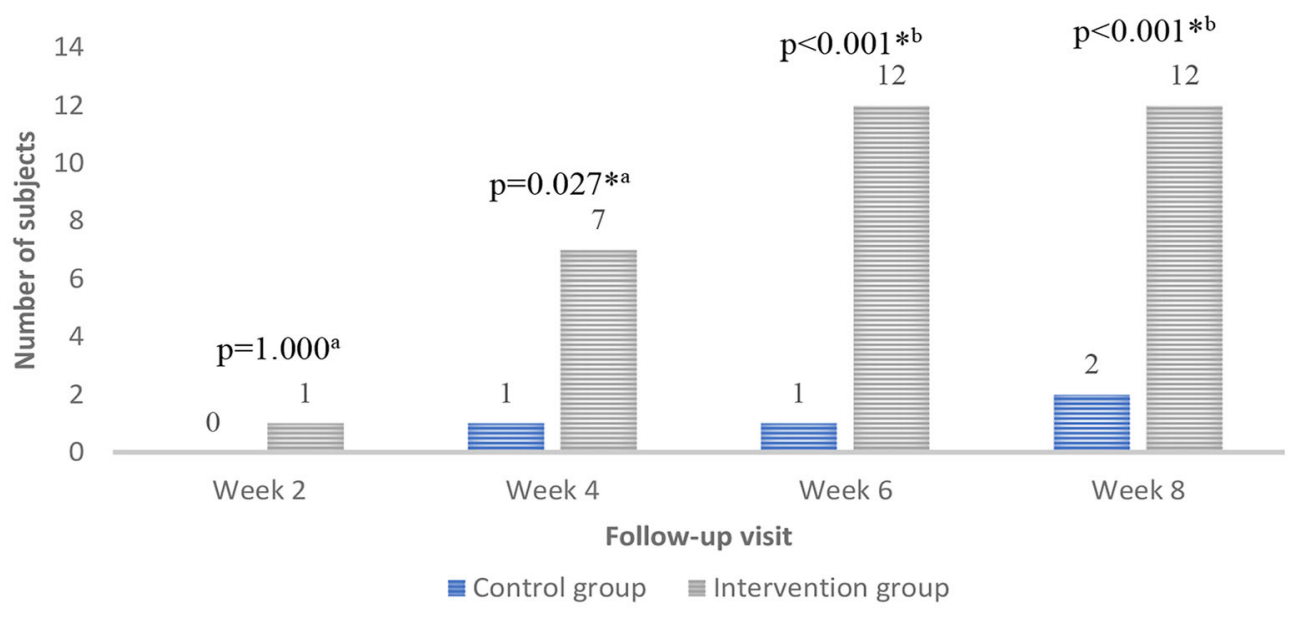

Fig. 2 Evaluation of SCORAD50 at each follow-up visit. $a=$ Fischer's exact test; $b=$ Chi-squared test; *statistically significant difference

Table 3 Changes in objective SCORAD score following intervention at week 2, 4, 6, and 8

\begin{tabular}{|c|c|c|c|c|}
\hline Variables & $\begin{array}{l}\text { Treatment group } \\
(n=12)\end{array}$ & $\begin{array}{l}\text { Control group } \\
(n=12)\end{array}$ & $p$-value ${ }^{+}$ & CI 95\% \\
\hline $\begin{array}{l}\triangle \text { Objective SCORAD score at week 2, mean } \\
\quad(\mathrm{SD})\end{array}$ & $11.68(4.82)$ & $5.23(5.89)$ & $0.004^{*}$ & $1.90-11.01$ \\
\hline $\begin{array}{l}\triangle \text { Objective SCORAD score at week } 4 \text {, mean } \\
\quad(\mathrm{SD})\end{array}$ & $18.82(7.70)$ & $7.81(6.43)$ & $0.001^{*}$ & $5.00-17.02$ \\
\hline $\begin{array}{l}\Delta \text { Objective SCORAD score at week } 6 \text {, mean } \\
\text { (SD) }\end{array}$ & $26.55(7.96)$ & $9.53(5.10)$ & $<0.001^{*}$ & $11.36-22.67$ \\
\hline $\begin{array}{l}\triangle \text { Objective SCORAD score at week } 8 \text {, mean } \\
(\mathrm{SD})\end{array}$ & $30.28(8.63)$ & $9.23(4.90)$ & $<0.001^{*}$ & $15.10-26.99$ \\
\hline
\end{tabular}

$C I$ confidence interval, $n$ number of subjects, SCORAD SCORing atopic dermatitis, $S D$ standard deviation *Statistically significant

${ }^{+}$Independent $t$-test

synergistic or opposite biological effects [10]. B cells are affected by histamine with various effects based on the type of receptor occupied. The production of antigen-induced antibodies independent to $\mathrm{T}$ cells will be decreased by inhibition of histamine- 1 receptor (H1R). The formation of $\operatorname{IgE}$ and IgG1 response against T-cell-dependent antigens will increase when $\mathrm{H} 1 \mathrm{R}$ is inhibited and will decrease when H2R is inhibited. The activation of H1R in B cells will also inhibit humoral immunity and increase cellular immunity so the inhibition of H1R will increase the formation of specific IgE. On the other hand, H2R activation in B cells will decrease cellular immunity so the inhibition of $\mathrm{H} 2 \mathrm{R}$ will decrease the formation of specific IgE $[10,11]$.

$\mathrm{T}$ cells have several receptors that can be affected by histamine. Th1 expresses a lot of H1R, whereas Th2 expresses more H2R. Activation of H1R on Th1 will increase the production of IFN $-\gamma$ and polarize towards Th1 while 
Table 4 Changes in visual analogue scale for pruritus and sleep following intervention at week 2, 4, 6, and $8(n=24)$

\begin{tabular}{llll}
\hline & Treatment group $(\boldsymbol{n}=\mathbf{1 2})$ & Control group $(\boldsymbol{n}=\mathbf{1 2})$ & $\boldsymbol{P}$-value $^{+}$ \\
\hline$\Delta$ VAS for pruritus at week 2 & $1.42 \pm 2.50$ & $1(-1$ to 4$)$ & $0.293^{-}$ \\
$\Delta$ VAS for pruritus at week 4 & $2.50 \pm 2.81$ & $0.92 \pm 1.31$ & $0.097^{+}$ \\
$\Delta$ VAS for pruritus at week 6 & $3.42 \pm 3.23$ & $0.83 \pm 1.11$ & $0.021^{*+}$ \\
$\Delta$ VAS for pruritus at week 8 & $3.92 \pm 3.26$ & $0.75 \pm 1.29$ & $0.007^{*+}$ \\
$\Delta$ VAS for sleep at week 2 & $1(0-5)$ & $0.5(0-1)$ & $0.343^{-}$ \\
$\Delta$ VAS for sleep at week 4 & $1(0-5)$ & $1(0-2)$ & $0.138^{-}$ \\
$\Delta$ VAS for sleep at week 6 & $1.5(0-5)$ & $1(0-3)$ & $0.133^{-}$ \\
$\Delta$ VAS for sleep at week 8 & $2.2 \pm 2.12$ & $1(-1$ to 3) & $0.159^{-}$ \\
\hline
\end{tabular}

Data are presented in mean \pm standard deviation if the distribution was normal and median (minimum-maximum) if the distribution was not normal

$n$ number of subjects

*Statistically significant

${ }^{+}$Independent $t$-test

${ }^{-}$Mann-Whitney test

Table 5 Comparison of serum IgE, IFN- $\gamma$, IL-4, and IL-12 levels before and after treatment $(n=24)$

\begin{tabular}{|c|c|c|c|c|c|c|}
\hline \multirow[t]{2}{*}{ Markers } & \multicolumn{3}{|l|}{ Before treatment } & \multicolumn{3}{|c|}{ After 8 weeks of treatment } \\
\hline & $\begin{array}{l}\text { Treatment } \\
\text { group }(n=12)\end{array}$ & $\begin{array}{l}\text { Control group } \\
(n=12)\end{array}$ & value $^{+}$ & $\begin{array}{l}\text { Treatment group } \\
(n=12)\end{array}$ & $\begin{array}{l}\text { Control group } \\
(n=12)\end{array}$ & $\begin{array}{l}p- \\
\text { value }^{+}\end{array}$ \\
\hline $\begin{array}{l}\text { IgE (IU/ml), median } \\
\text { (interquartile range) }\end{array}$ & $495.50(765.35)$ & $492.45(1.233 .5)$ & 0.849 & $337(315.35)$ & $643.50(1.046 .9)$ & $0.015^{*}$ \\
\hline $\begin{array}{l}\text { IFN- } \gamma(\mathrm{pg} / \mathrm{ml}) \text {, median } \\
\text { (interquartile range) }\end{array}$ & $254.96(168.26)$ & $229.02(231.26)$ & 0.665 & $261.67(216.45)$ & $170.69(219.055)$ & 1.000 \\
\hline $\begin{array}{l}\mathrm{IL}-12(\mathrm{pg} / \mathrm{ml}), \text { median } \\
\quad \text { (interquartile range) }\end{array}$ & $3.53(3.41)$ & $2.43(4.14)$ & 0.386 & $2.05(3.84)$ & $3.89(3.395)$ & 0.312 \\
\hline $\begin{array}{l}\mathrm{IL}-4(\mathrm{pg} / \mathrm{ml}), \text { median } \\
\text { (interquartile range) }\end{array}$ & $19.09(12.11)$ & $13.31(12.33)$ & 0.326 & $22.67(19.22)$ & $12.10(42.71)$ & 0.298 \\
\hline
\end{tabular}

$I F N$ interferon, $I g E$ immunoglobulin E, $I L$ interleukin, $I U$ international unit, $m l$ millilitre, $n$ number of subjects; $p g$ picogram

${ }^{*}$ Statistically significant

${ }^{+}$Mann-Whitney test

activation of H2R will inhibit this effect. Activation of H2R will also increase IL-10 production, which serves to suppress the excessive immune responses and inhibit secretions of IL4, IL-5, and IL-13, Th1 response as well as Th2 cell proliferation. Hence, administration of H2RA will lead to increased production of IL-4 and IFN- $\gamma$. On the other hand, inhibition of $\mathrm{H} 1 \mathrm{R}$ in $\mathrm{T}$ cells will lead to suppression of IFN- $\gamma$ 
production and increased production of IL-4 and IL-13 [11].

\section{Changes in SCORAD, Objective SCORAD Scores, and Subjective Symptoms}

Several tools have been developed to measure the severity of $\mathrm{AD}$ but none has been established as a gold standard. The most commonly used tools are SCORAD and objective SCORAD, Eczema Area and Severity Index (EASI), and Six Sign Atopic Dermatitis (SASSAD) [2, 12]. EASI and SCORAD are established as the best instruments for evaluation of $\mathrm{AD}$ severity based on clinical signs with good reliability $[13,14]$. SCORAD has sensitivity of $65 \%$ and specificity of $64 \%$ while objective SCORAD has sensitivity of $55 \%$ and specificity of $79 \%[15,16]$. In this study, the mean SCORAD score at baseline was 43.90 in the treatment group (severe AD) and 35.23 in the control group (moderate $\mathrm{AD}$ ). Similarly, the objective SCORAD score was 36.98 in the treatment group (moderate AD) and 28.90 in the control group (moderate AD). These results are consistent with studies showing that most patients with moderate to severe AD require systemic medications [17]. This study used objective SCORAD scoring to determine whether there were different results if the subjective element in SCORAD was eliminated because the administration of H1RA (cetirizine) could reduce itching and provide a sedative effect, which subsequently affect the subjective complaints of the subjects.

The SCORAD scores showed a significant improvement after 2 weeks of treatment. Significant SCORAD changes from 2 weeks of treatment mean $\mathrm{AD}$ patients will begin to feel clinical improvement after 2 weeks and continue to improve if continued for up to 8 weeks. Evaluation of SCORAD50 showed significantly higher proportions in the intervention group compared to the control group. Similarly, significant differences were also found in objective SCORAD changes after treatment of $2,4,6$, and 8 weeks. In addition, the changes in VAS for pruritus and sleep were always superior in the intervention group even though only changes in VAS for pruritus at week 6 and 8 showed significant differences. This suggests that administering cimetidine significantly lowers the severity of AD after 2 weeks. There was a role of cimetidine in reducing SCORAD scores due to the decreased production of IgE through inhibition of mast cell degranulation and increased secretion of IL-10 [18, 19].

\section{Changes in Serum IgE Level}

Measurements of serum IgE, IFN- $\gamma$, IL-12, and IL-4 levels aim to determine whether the clinical improvements showed by the changes in SCORAD and objective SCORAD scores are accompanied by changes in immunoglobulins or cytokines involved in $\mathrm{AD}$ pathogenesis. At baseline, the median IgE level was $495.50 \mathrm{IU} / \mathrm{ml}$ in the treatment group and $492.45 \mathrm{IU} / \mathrm{ml}$ in the control group. Various studies have shown large variations of IgE levels in AD patients, ranging from 150 to 20,000 IU/ml [5]. IgE has been strongly associated with $\mathrm{AD}[20]$. The higher the IgE level is, the more severe is $\mathrm{AD}$ as measured by SCORAD [21]. At the end of this study, the median IgE level decreased in the treatment group but increased in the control group with significant differences in the changes in $\operatorname{IgE}$ level between the two groups. These results suggest that administering cimetidine for 8 weeks significantly lowers serum IgE levels better than placebo. Despite being rare, the decline of IgE levels in a short period of time was demonstrated in previous studies. Kasperkiewicz et al. demonstrated $92 \%$ reduction of IgE level in 1 week after IgE-selective immunoadsorption therapy [22]. Another study by Zink et al. also reported significant reduction of IgE levels (64\%) within 5 days after IgE-selective immunoadsorption therapy [23].

In this study, all subjects also received oral cetirizine as standard AD treatment. Cetirizine is a H1RA [24]. Hence, the effect that occurred in B cells or plasma cells in this study was a combination of inhibitory effects of H1R and H2R. In this study, the decrease in serum IgE level was due to the inhibitory effect of H2R, which was greater than that of $\operatorname{H1R}[10,11]$. Cimetidine is known to block the degranulation of mast cells, which reduces the production of 
IgE by IL-4 [18]. In addition, inhibition of H2R by cimetidine results in increased IL-10. IL-10 reduces the production and class switching into IgE [19]. Hence, these effects reduce the IgE level in the treatment group, leading to decreased subjective and objective improvements, which were proven by the significantly higher decrease in mean SCORAD and objective SCORAD scores of the treatment group at the end of the study.

\section{Changes in Serum IFN- $\gamma$ Level}

At baseline, median IFN- $\gamma$ level was higher in the treatment group. At the end of the study, there was no significant difference in median IFN- $\gamma$ levels between the treatment group and control group. Despite no significant differences between the two groups, there was an increase in median IFN- $\gamma$ level after 8 weeks. This suggests that inhibition of H1R and H2R in Th1 cells was equal. Increased IFN- $\gamma$ production suppressed the activation of Th2 and decreased the production of cytokines by these cells, namely IL-4, IL-5, and IL-13 [11]. Another study also reported that cimetidine did not influence the IFN- $\gamma$ production, as seen in this study. From each histamine receptor antagonist, only H1R and histamine-4 receptor antagonist were shown to decrease IFN- $\gamma$ production [25].

\section{Changes in Serum IL-12 Level}

At baseline, median IL-12 level was higher in the treatment group. At the end of the study, there was no significant difference in median IL12 levels between the treatment and control group. Cimetidine administration will inhibit $\mathrm{H} 2 \mathrm{R}$ on dendritic cells, thus increasing IL-12 production [26]. However, the subjects also received cetirizine so the effect was a result of inhibition of both H1R and H2R. The results indicate equal inhibition of H1R and H2R in dendritic cells.

\section{Changes in Serum IL-4 Level}

At baseline, median IL-4 level was higher in the treatment group. At the end of the study, there was no significant difference in median IL-4 levels between the treatment and control groups. Theoretically, cimetidine will decrease IL-4 production indirectly by increasing IFN- $\gamma$ production, which will subsequently reduce the activation of Th2 and decrease cytokine production [11]. However, the subjects also received cetirizine, a H1RA, which suppresses IFN- $\gamma$ production and subsequently increases IL4 production. In addition, while cimetidine augments Th2 responses, it also augments Th1 responses. As a result, the augmented Th2 cytokines were suppressed by the Th1 responses, as seen in this study [27].

Despite promising outcomes and no serious adverse events due to the use of cimetidine, there were several limitations of this study, which were the short follow-up period, small sample size, and no evaluation on EASI50. Future studies with cross-over methods and longer follow-up periods are warranted to eliminate individual heterogeneity. In addition, correlation to food-related radioallergosorbent test (RAST) values, lactate dehydrogenase $(\mathrm{LDH})$, and peripheral eosinophils should be investigated.

\section{CONCLUSIONS}

Based on these results, cimetidine is effective and safe as an adjuvant therapy to standard AD treatment. Cimetidine is proven to have immunomodulatory effects in cases of moderate-severe $\mathrm{AD}$ by inhibiting $\mathrm{H} 2$ receptors as well as lowering IgE level. In addition, cimetidine can prevent the progression of acute extrinsic $\mathrm{AD}$ into chronic $\mathrm{AD}$ due to excessive increase of serum IFN- $\gamma$. Furthermore, all subjects received oral cetirizine, which could exert biological effects opposing cimetidine in some immune cells, proven by there being no changes in serum IFN- $\gamma$, IL-12, and IL-4 levels. Therefore, the inhibitory effect of cimetidine is superior in $B$ cells and plasma cells but inferior in dendritic cells and $\mathrm{T}$ cells compared to the inhibitory effect of cetirizine. 


\section{ACKNOWLEDGEMENTS}

We thank the participants of the study.

Funding. No funding or sponsorship was received for this study or publication of this article. The Rapid Service Fee was funded by the authors.

Authorship. All named authors meet the International Committee of Medical Journal Editors (ICMJE) criteria for authorship for this article, take responsibility for the integrity of the work as a whole, and have given their approval for this version to be published.

Author Contributions. All authors contributed to the study conception and design. Material preparation, data collection, and analysis were performed by Endi Novianto. The first draft of the manuscript was written by Endi Novianto, and all authors commented on previous versions of the manuscript. All authors read and approved the final manuscript.

Disclosures. Endi Novianto, Tjut Nurul Alam Jacoeb, Wresti Indriatmi, Suhendro, Rianto Setiabudy, Rahajuningsih D. Setiabudy, Murdani Abdullah, Iris Rengganis, Oki Suwarsa, and Retno Widowati Soebaryo declare that they have nothing to disclose.

Compliance with Ethics Guidelines. The study was conducted in accordance with the Declaration of Helsinki, the International Conference on Harmonization Good Clinical Practice guideline, and applicable regulatory requirements. This study has been reviewed and approved by Health Research Ethics Committee of Faculty of Medicine Universitas Indonesia, approval number 1075/UN2.F1/ETIK/2017. All patients provided written informed consent before participating in the study.

Data Availability. The data sets generated during and/or analyzed during the current study are available from the corresponding author on reasonable request.
Open Access. This article is licensed under a Creative Commons Attribution-NonCommercial 4.0 International License, which permits any non-commercial use, sharing, adaptation, distribution and reproduction in any medium or format, as long as you give appropriate credit to the original author(s) and the source, provide a link to the Creative Commons licence, and indicate if changes were made. The images or other third party material in this article are included in the article's Creative Commons licence, unless indicated otherwise in a credit line to the material. If material is not included in the article's Creative Commons licence and your intended use is not permitted by statutory regulation or exceeds the permitted use, you will need to obtain permission directly from the copyright holder. To view a copy of this licence, visit http://creativecommons.org/licenses/by$\mathrm{nc} / 4.0 /$.

\section{REFERENCES}

1. Abuabara K, Yu AM, Okhovat JP, Allen IE, Langan SM. The prevalence of atopic dermatitis beyond childhood: A systematic review and meta-analysis of longitudinal studies. Allergy. 2018;73(3): 696-704.

2. Eichenfield LF, Tom WL, Berger TG, Krol A, Paller AS, Schwarzenberger $\mathrm{K}$, et al. Guidelines of care for the management of atopic dermatitis: Section 2. Management and treatment of atopic dermatitis with topical therapies. J Am Acad Dermatol. 2014;71(1):116-32.

3. Kabashima K. New concept of the pathogenesis of atopic dermatitis: Interplay among the barrier, allergy, and pruritus as a trinity. J Dermatol Sci. 2013;70(1):3-11.

4. Leung DY, Guttman-Yassky E. Deciphering the complexities of atopic dermatitis: shifting paradigms in treatment approaches. J Allergy Clin Immunol. 2014;134(4):769-79.

5. Kulthanan K, Boochangkool K, Tuchinda P, Chularojanamontri L. Clinical features of the extrinsic and intrinsic types of adult-onset atopic dermatitis. Asia Pac Allergy. 2011;1(2):80-6.

6. Koszorú K, Borza J, Gulácsi L, Sárdy M. Quality of life in patients with atopic dermatitis. Cutis. 2019;104(3):174-7. 
7. Sidbury R, Davis DM, Cohen DE, Cordoro KM, Berger TG, Bergman JN, et al. Guidelines of care for the management of atopic dermatitis: section 3 . Management and treatment with phototherapy and systemic agents. J Am Acad Dermatol. 2014;71(2):327-49.

8. De Benedetto A, Yoshida T, Fridy S, Park JE, Kuo IH, Beck LA. Histamine and skin barrier: are histamine antagonists useful for the prevention or treatment of atopic dermatitis? J Clin Med. 2015;4(4):741-55.

9. Sinha S, Relhan V, Garg VK. Immunomodulators in warts: Unexplored or ineffective? Indian J Dermatol. 2015;60(2):118-29.

10. Branco ACCC, Yoshikawa FSY, Pietrobon AJ, Sato MN. Role of histamine in modulating the immune response and inflammation. Mediators Inflamm. 2018;2018:9524075.

11. O'Mahony L, Akdis M, Akdis CA. Regulation of the immune response and inflammation by histamine and histamine receptors. J Allergy Clin Immunol. 2011;128(6):1153-62.

12. Chopra R, Silverberg JI. Assessing the severity of atopic dermatitis in clinical trials and practice. Clin Dermatol. 2018;36(5):606-15.

13. Schmitt J, Langan S, Deckert S, Svensson A, von Kobyletzki L, Thomas K, et al. Assessment of clinical signs of atopic dermatitis: a systematic review and recommendation. J Allergy Clin Immunol. 2013;132(6):1337-47.

14. Bożek A, Reich A. Assessment of intra- and interrater reliability of three methods for measuring atopic dermatitis severity: EASI, Objective SCORAD, and IGA. Dermatology (Basel, Switzerland). 2017;233(1):16-22.

15. Schram ME, Spuls PI, Leeflang MM, Lindeboom R, Bos JD, Schmitt J. EASI, (objective) SCORAD and POEM for atopic eczema: responsiveness and minimal clinically important difference. Allergy. 2012;67(1):99-106.

16. Goh YY, Keshavarzi F, Chew YL. Prevalence of atopic dermatitis and pattern of drug therapy in Malaysian children. Dermatitis. 2018;29(3):151-61.

17. Roekevisch E, Spuls PI, Kuester D, Limpens J, Schmitt J. Efficacy and safety of systemic treatments for moderate-to-severe atopic dermatitis: A systematic review. J Allergy Clin Immunol. 2014;133(2): 429-38.

18. Carlos D, Sa-Nunes A, de Paula L, Matias-Peres C, Jamur MC, Oliver C, et al. Histamine modulates mast cell degranulation through an indirect mechanism in a model IgE-mediated reaction. Eur J Immunol. 2006;36(6):1494-503.

19. Lin AA, Freeman AF, Nutman TB. IL-10 indirectly downregulates IL-4-induced IgE production by human B cells. Immunohorizons. 2018;2(11): 398-406.

20. Ahmed I, Nasreen S. Frequency of raised serum IgE level in childhood atopic dermatitis. JPMA J Pak Med Assoc. 2007;57(9):431-4.

21. Zedan K, Rasheed Z, Farouk Y, Alzolibani AA, Bin Saif G, Ismail HA, et al. Immunoglobulin e, interleukin-18 and interleukin-12 in patients with atopic dermatitis: correlation with disease activity. J Clin Diagn Res JCDR. 2015;9(4):Wc01-5.

22. Kasperkiewicz M, Mook SC, Knuth-Rehr D, Vorobyev A, Ludwig RJ, Zillikens D, et al. IgE-selective immunoadsorption for severe atopic dermatitis. Front Med. 2018;5:27.

23. Zink A, Gensbaur A, Zirbs M, Seifert F, Suarez IL, Mourantchanian $\mathrm{V}$, et al. Targeting $\operatorname{IgE}$ in severe atopic dermatitis with a combination of immunoadsorption and omalizumab. Acta Derm Venereol. 2016;96(1):72-6.

24. Jordakieva G, Kundi M, Lemell P, Zieglmayer R, Zieglmayer P, Jensen-Jarolim E, et al. Cetirizine inhibits gender-specific blood cell dynamics upon allergen contact in allergic rhinitis. Clin Immunol. 2020;215:108422.

25. Kamei M, Otani Y, Hayashi H, Nakamura T, Yanai $\mathrm{K}$, Furuta K, et al. Suppression of IFN- $\gamma$ production in murine splenocytes by histamine receptor antagonists. Int J Mol Sci. 2018;19(12):4083.

26. Zundler S, Neurath MF. Interleukin-12: functional activities and implications for disease. Cytokine Growth Factor Rev. 2015;26(5):559-68.

27. Arae K, Oboki K, Ohno T, Hirata M, Nakae S, Taguchi $\mathrm{H}$, et al. Cimetidine enhances antigenspecific IgE and Th2 cytokine production. Allergol Int. 2011;60(3):339-44. 